\title{
THE PROFILE OF A PERFECT TEACHER: VULPE T. BUJOR-COSTICĂ \\ (1924-1983)
}

\author{
AL. PĂCURAR ${ }^{1}$
}

\begin{abstract}
The Profile of a Perfect Teacher: Vulpe T. Bujor-Costică (1924-1983). Vulpe T. Bujor-Costică was for a short time a member of Institute of Geography belonging to Cluj University. In the second year as a student, he was asked by the head of the institute, professor Sabin Opreanu, to become a drawer at the Institute and he had this job between April and September 1947. Originating from an ancient Romanian family in Orăștie, Vulpe T. Bujor-Costică has been educated at the pre-communist Cluj Geographical School, whose bases were laid by the scientist George Vâlsan. He graduated in 1953 with a major in Geography, within the Faculty of Sciences of Cluj University. Between 1957 and 1983 he was a teacher at the Cluj School for Blind and Visually Impaired and an author of school books in Braille alphabet. At the same time, he activated in the "Iacob Mureșianu" male choir of the Cluj Culture Centre.
\end{abstract}

Keywords: drawer, Institute of Geography, teacher, Geography school books, Braille alphabet.

Out of the bright gallery of the members of the Institute of Geography belonging to Cluj "King Ferdinand I" University, which existed between 1919 and 1947, the figure of Vulpe T. Bujor-Costică was a meteoric sight, from spring to autumn 1947. During this period, as a Geography student in the second year at the Faculty of Sciences of the university, he was given the job at the Institute of Geography by professor Sabin Opreanu, who was head of the Institute of Geography in the most difficult period of its existence (September 1, 1941, to September 1, 1947), until he was fired with the arrival of the communists. In line with the good traditions of the institute, professor Opreanu hired in spring 1947 the hardworking $2^{\text {nd }}$ year student for the position of drawer.

\footnotetext{
1 Babeș-Bolyai University, Faculty of Geography, 5-7 Clinicilor Street, Cluj-Napoca, Romania, e-mail: alexandru.pacurar@ubbcluj.ro.
} 
The political and social context of this period was very gloomy, as Romania was occupied by the Red Army. Under its protection, the Soviets and their Romanian fellows began a diabolical process to turn the country into a communist one. During this, the leaders of the historical political parties were annihilated, the best officers were removed from the Romanian Army, the economy suffered a continuous erosion as the trade unions became involved politically, the smartest scientists, teachers and highbrows were set aside from education and the cultural environment.

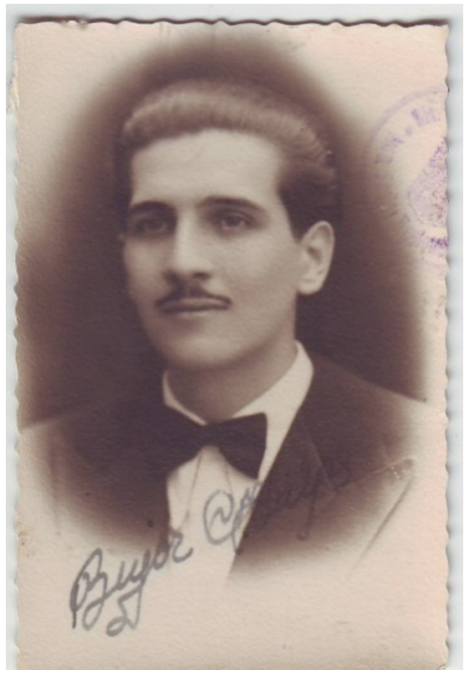

The student Vulpe T. BujorCostică in the 1945/1946 academic year

In this difficult atmosphere, in the summer of 1945 , the university with all its institutions returned from its refuge to Cluj. However, the social and political climate was agitated because of the Soviet military occupation which began to demolish the country by setting the communist into power, a process which peaked with the abusive and antidemocratic change of the constitutional order by forcing the abdication of King Michael I on 30 December 1947. Then, a group sold to Moscow and under the Soviet protection has conducted the proclamation in Parliament of the Romanian People's Republic. The development of the events is described in the well-documented book of Eliodor Focşeneanu (1997), Două săptămâni dramatice din istoria României (17-30 decembrie 1947), which translates as Two dramatic weeks in the history of Romania (17-30 December 1947), All Publishing House, Bucharest. For half a century, this established the communist dictatorship in Romania, the so-called leadership of the working class, in reality led by less than mediocre people, supporting atheism and Comintern internationalism, concepts foreign to the vast majority of Romanians. Who were these "revolutionists"? The last democratically elected prime minister of Romania, general Nicolae Rădescu, described what the negotiations to form the government looked like (Demetriade, Șerbănescu, 2015, pp. 121-122): "Because the first attempt to form the government [the negotiations, s.n.] was interrupted in the last minute due to the hostility of Ana Pauker, agent of the Russians [...], I started a consultation of all the groups [...]. I contacted Pătrăşcanu, who was apparently the leader of the Communist Party [...]. Although not only the communists, but also the members of the F.N.D. [National Democratic Front] were all present, only two people participated in the discussions... Luca [Vasile, in reality László, s.n.] and Ana Pauker [in reality Hanna Robinsohn, s.n.]. They were both coarse and provocative, at the same time, they were lacking 
the formation and education for the assumed role of leaders. From the very beginning I realized I will meet their hostility. In fact, from the first moment the atmosphere became hostile because, when talking about Bessarabia, both of them very promptly asserted that this province has never been Romanian and therefore Romania had no right for it". So this is the profile of the country destroyers. In a normal state, all the decisions taken from institutions led by such people would have been declared void!

In this very bleak context, in the summer of 1945, "King Ferdinand I" University returned gradually to Cluj from its refuge at Sibiu and Timişoara, until the autumn of the same year, when the 1945-1946 academic year started. The moment of return from its refuge is described by Mrs. Dumbravă HoraCrăiţa (September 2016), daughter of the teaching assistant Fabiu I. Dumbravă from the Institute of Geography, then a young girl who was 10-11 year old: "I came back from the refuge in Timişoara with my parents in the summer of 1945. For my parents, as well as for other teachers and their families, the university made available a train coach where we put all our furniture and belongings. Once we arrived at Cluj railway station, after an exhausting voyage, our belongings were loaded in a military truck and transported to the University, where they were downloaded and stored in the basement of the building. We also stayed there for about two weeks, together with other university staff families, until we were provided accommodation in the city. The inner court, the corridors of the university and also the street of the university vibrated because of our voices and our childhood games, as we were happy to return home". With the new "leaders" of the country fraudulently set by the Soviet commanders, "King Ferdinand I" University entered a new stage of its existence. In the beginning, some skilled teachers were "compressed", meaning that they were removed, as they had been clerks of the former political regime. Many of them were highbrows, like the secretary general of the university, Ioan A. Vătăşescu, rejected by the "trade union members". In 1945, faithful citizens of the country where they lived, some Hungarian nationals gained profit of the Soviet occupation and established in Cluj a Hungarian university named "Bolyai János". In 1948, "King Ferdinand I" University was renamed at once... "Victor Babeş". Later, in 1959, the two universities problematically merged becoming "Babeş-Bolyai" University.

In the context of the year 1947, professor Sabin Opreanu selected Vulpe T. Bujor-Costică, then a Geography student in the second year, as a member of the Institute of Geography which he headed, providing him the position of drawer. Of course, the professor have seen the student as a hopeful element, as he originated from a great family of Romanian patriots, who contributed to the enforcement of the national sentiment in Transylvania, which became manifest across the entire united country after the First World War. 
The family and formation of the teacher Vulpe T. Bujor-Costică are defining elements of his profile and personality. He was born on 30 September 1924, at Orăştie, the youngest son of Vulpe Teodor and Vulpe Alexandrina. Vulpe Teodor originated from Felnac, Arad County, and he became a "landlord and forest trader in Orăştie" founding member of the Romanian Forestry company in Cluj (the newspaper "Românul" [the Romanian], Arad, no. 187, 20 December 1919, p. 4, accessed on documente.bcucluj.ro/web/bibdigit/periodice/), then general manager of Dacia Bank in Orăştie. Alexandrina Vulpe originated from Strei, near Călan, Hunedoara County, and was a "raving beauty" in her youth. The couple had four children, three boys: Iulian Romulus, Tudor Lucian and Bujor-Costică, and one daughter, Stella Sofia. Vulpe Teodor was a graduate of the Faculty of Theology in Arad and became a prosperous businessman in Orăştie due to his

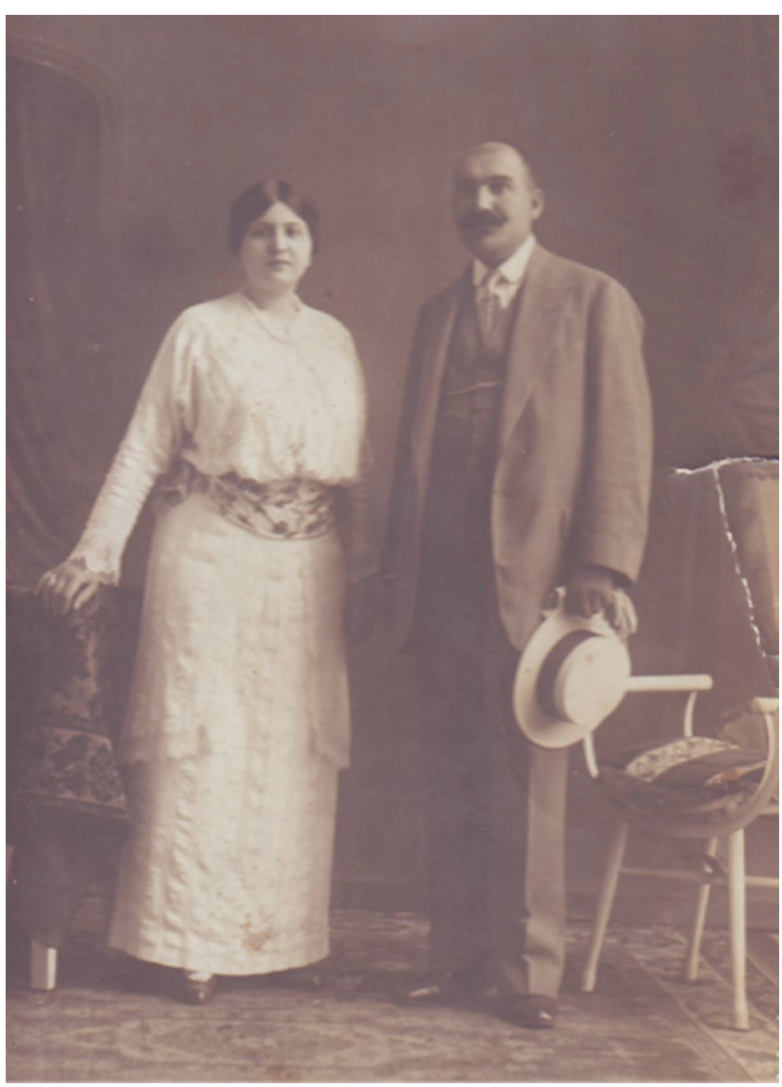

The parents Vulpe Teodor (1883-1931) and Vulpe Alexandrina (1880-1946) own merits, a forest trader and owner of a furniture shop. In the memory of the family, he is remembered as "handsome, distinguished and elegant".

Due to his enterprising nature, he was named head of Deva Chamber of Commerce. Politically, he was a member of the Liberal Party and in this quality he became mayor of Orăştie between May 1929 and 31 July 1931, when he died prematurely. His demise was caused by the grief induced by the death of his daughter, Stella Sofia. She was 18 years old and attended the courses of a boarding school in Vienna when she contacted a galloping pneumonia that caused her death; her father died within a month. Vulpe Alexandrina lived for another 15 years and died in 1946, when Vulpe T. Bujor-Costică was student in the first year in Cluj. 
Vulpe T. Bujor-Costică attended and graduated in 1945 the high school courses at "Aurel Vlaicu" High School in Orăştie, an elite Romanian high school, established in 1919. There, he acquired knowledge, skills, a proactive attitude towards work, a high civic and patriotic spirit, under the guidance of exceptional teachers. Many of his teachers could have been successfully included in university departments, as was the case of his Geography teacher, Ioachim Rodeanu, former assistant at the Institute of Geography at Cluj University between 1920 and 1923, who opted however for a teaching position at the high school in Orăștie, closer to his native village.

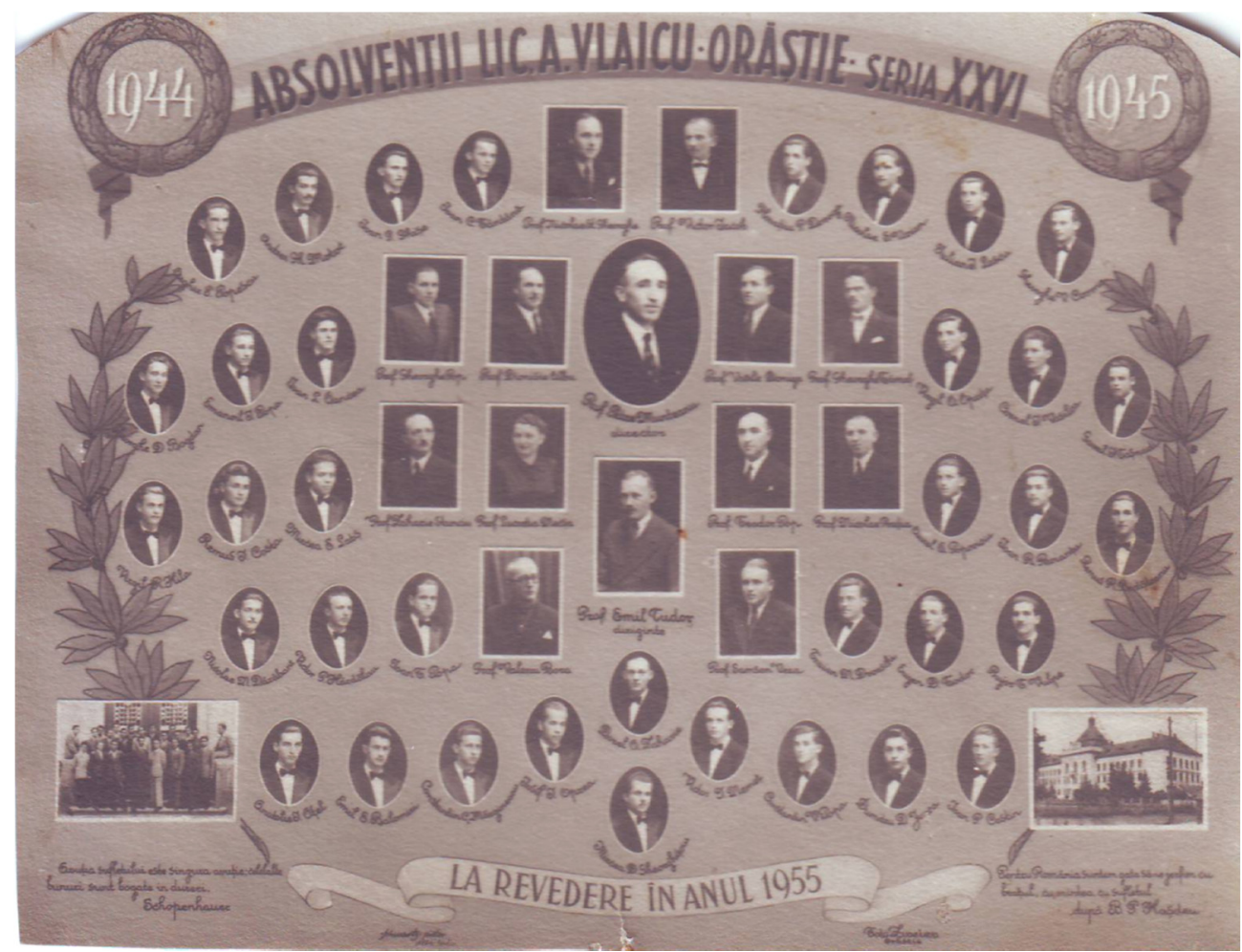

The graduates of "Aurel Vlaicu" High School in Orăștie, class of 1945, and their teachers (young Vulpe is the sixth - the last - in the fourth row, to the right)

Strongly influenced by the personality of his high school Geography teacher, whose lessons in class were completed by field trips and holiday camps throughout the entire country, in this true civic and patriotic school called "Străjeria" (the Boy Scouts), the young bachelor opted for the Geography university 
courses which he attended at the Geography section of the Faculty of Sciences within "King Ferdinand I" University of Cluj. In the second year of studies (19461947), in the spring of 1947, he was hired as a drawer at the Institute of Geography of the university by the head of the Institute, professor Sabin Opreanu. He had this position only for a few months because in September 1947 he was no longer mentioned among the employees of the Institute, as he was dismissed from all the functions; in fact, the head of the institute was also removed. The new regime did not need young people coming from solid Romanian families, belonging to the bourgeoisie. It is all the same a miracle that in 1953, during the worst period of communism (1948-1962), he succeeded to complete his studies at the Faculty of Geology-Geography at "Victor Babeş" University of Cluj, becoming a graduate after several interruptions caused by diverse reasons. One of the reasons was however a happy event, the marriage to Suciu Lucreția on the $3^{\text {rd }}$ of May 1948. The couple had a happy marriage, blessed by the birth of a daughter, Vulpe Alexandrina Lucreţia, on the $18^{\text {th }}$ of April 1952. She is now a distinguished teacher of French Language and Literature in Cluj, receiving the first (highest) level of teacher certification in 2004.

The professional activity of Vulpe T. Bujor-Costică is rich, vast and diversified. While a student, he was involved in different activities. Apart from

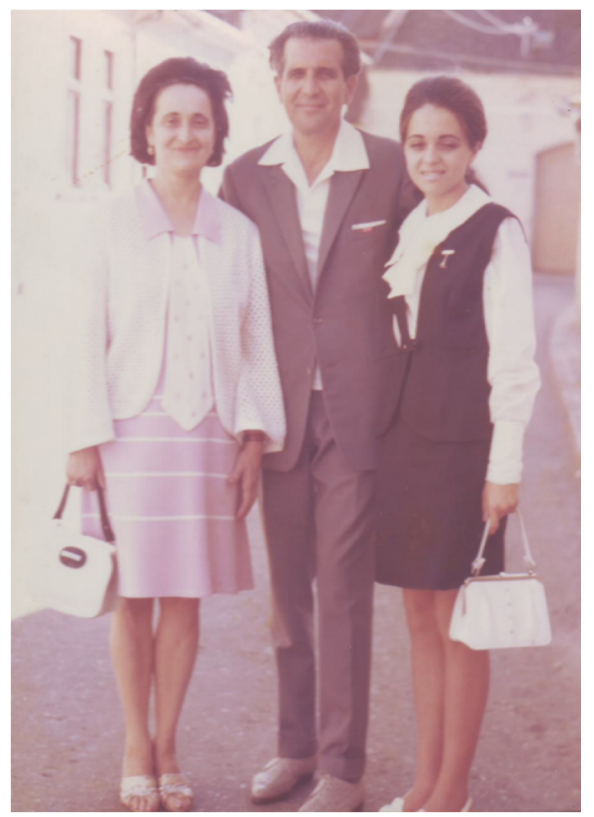

Le professeur Vulpe T. Bujor-Costică (1924-1983) avec son épouse et leur fille, en 1971 the position of drawer at the Institute of Geography (1947), he was employed in the office of the Romanian Railways Company (CFR) between 1948 and 1949 and then as a teacher at the CFR Vocational School in Cluj. After the graduation, he was a Geography teacher at the CFR Vocational School and then at the Food Industry Technical School (1953-1955), a mixed general sevenyear school (1955-1957) and the Special School for the Blind and Deaf (1957-1959). In this difficult part of the communist period, he was a school inspector for a short period of time (1951). The activities performed in these positions allowed him to cover his "unhealthy" bourgeois origins. He finally succeeded to become a tenure Geography teacher at the Special School for Blind and Visually Impaired in Cluj in 1959, where he worked until his premature death in 1983, aged only 59. 
Dedicated to his work as a teacher, as he learned from his teachers in high school and university, motivated by the passion to "enlighten" the blind, professor Vulpe T. Bujor Costică authored, together with Gheorghe Stanciu, the first Romanian Geography school books in Braille, a writing system designed for the visually impaired, in which the letters are represented by raised dots, which are identified by touching them with the fingers. Having in mind the visually impaired, the two teachers authored Geography school books for the $4^{\text {th }}$ form, "The Geography of Iaşi Region" and "The Geography of Ploieşti Region". As far as we know, Vulpe T. Bujor-Costică is the only member of the Institute of Geography of Cluj University who has written Geography school books in Braille for the visually impaired. In 1969 he received the first (highest) level of teacher certification. The brave professor had also a remarkable cultural activity as a member of "Iacob Mureşianu" male choir at Cluj City Culture Centre, under the direction of Marius Cuteanu. The choir was established in 1970 and the honorary president was Ştefan Pascu, member of the Romanian Academy. The first director was professor Romeo Ghircoiaşu from "Gheorghe Dima” Musical Conservatory of Cluj.

Animated by the desire to enlighten by teaching to his pupils, convinced that "nothing is more beautiful and noble than being a teacher" (Dumitru Almaş), professor Vulpe T. Bujor-Costică educated and formed many generations of students. He also injected the passion for teaching and for the profession of teacher to his daughter, Alexandrina Lucreţia. A valued teacher in Cluj, she confessed: "Ever since I was a child, the pedagogical atmosphere created by my father guided my steps towards a teaching career. I am a graduate of the Faculty of Letters in 1977 and a teacher of French, a subject of study suggested by my father who helped me a lot with the lessons because he also had a deep knowledge of this language". In this way, the passion for teaching was passed over to his daughter who tried to reach the level of her father. In December 2002, as a teacher at "Mihai Eminescu" High School of Cluj, she published an auxiliary school book for the usage of pupils and teachers - "Une autre façon d'enseigner la phonétique" ("Another manner to teach Phonetics"), accompanied by an audio cassette. She guided the pedagogical practice of the students of French at the Faculty of Letters.

A year later, she published another auxiliary school book - "Une autre façon d'enseigner les themes" ("Another manner to teach the subjects"). In 2003 she guided once again the students of French pedagogical practice in the high school and, as she asserted "it is not a mere coincidence that these students come from the Geography and French specialization, which proves that nothing is really random". This is, certainly, the manner in which the daughter cherished once again the memory of her father, the Geography teacher Vulpe T. Bujor-Costică, as she followed his example! She provided the photos inserted in the text. Important 
pieces of information have been given by his cousin, the honorable Mr. Vulpe Teodor Marius, who lives in the house of his grandparents in the centre of Orăştie and who is the most competent depositary of their grandparents' memory. Other pieces of information were provided by their cousin, Mrs. Cîrje Stella Ileana, a former teacher in Cluj, now retired. I thank all of them for their cooperation!
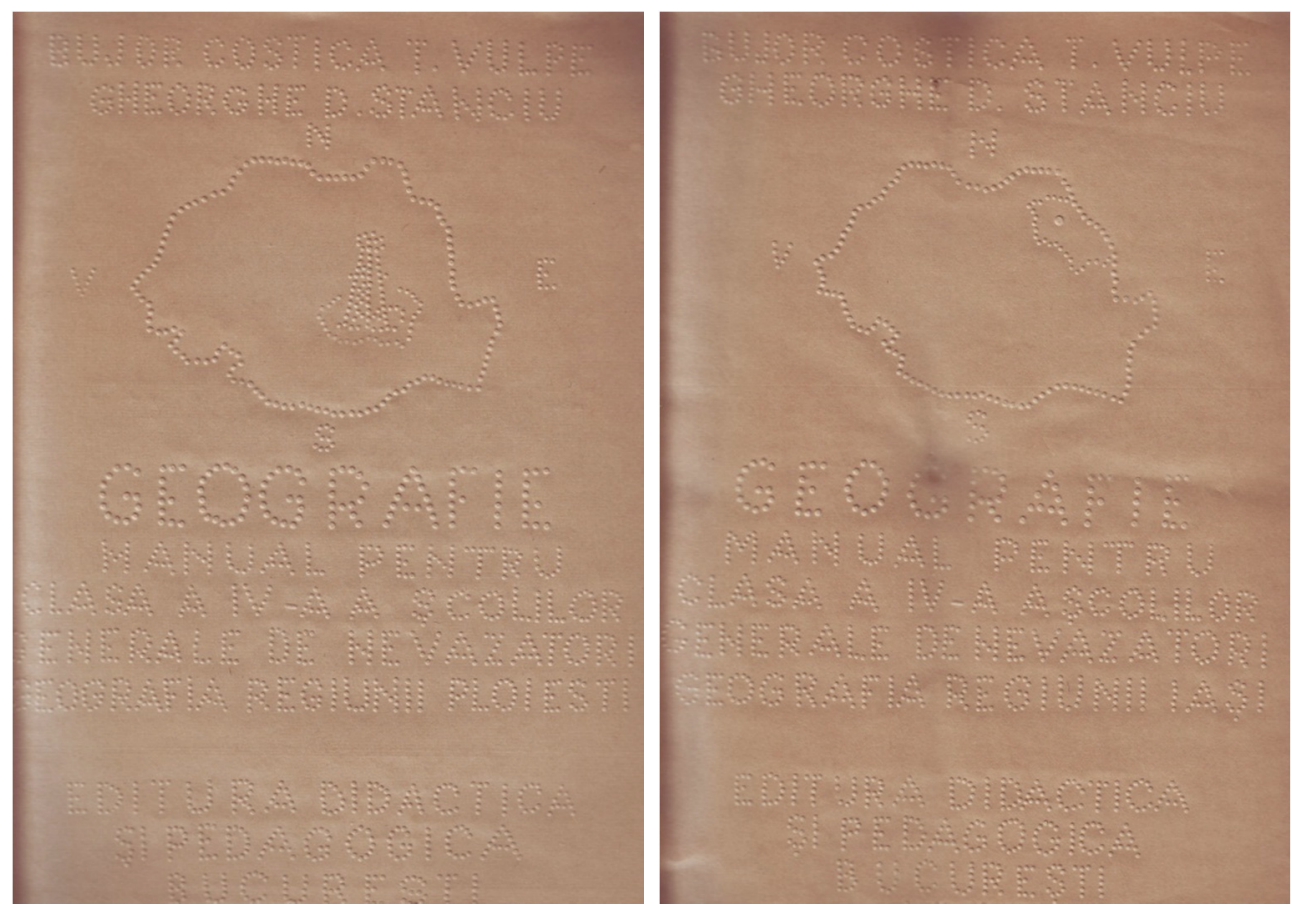

The covers of the Geography school books for the $4^{\text {th }}$ primary form, in Braille, whose first author is Vulpe T. Bujor-Costică

The short presentation of the life and activity of Vulpe T. Bujor-Costică, teacher and former member of the Institute of Geography belonging to "King Ferdinand I" University of Cluj, a true school for the professional and civic formation of young researchers, is enrolled in the efforts to convey to posterity the bright figures of this institute, whose foundations were laid by the determination and passion of professor George Vâlsan. Compared to the derisive disciples of today, their life and activities, dedicated to the development of the community and of the homeland, are examples that deserve to be followed! 


\section{REFERENCES}

1. Demetriade, O. I., Şerbănescu, Al. (2015). Generalul Nicolae Rădescu. Profilul unui om de stat în imagini și documente, Edit. Oscar Print, București.

2. Focşeneanu, E. (1997). Două săptămâni dramatice din istoria României (17-30 decembrie 1947), Edit. All, București.

3. "Românul" (newspaper) (1919). No. 187, 20 December 1919, p. 4, Arad, accessed on: documente.bcucluj.ro/web/bibdigit/periodice/ 